\title{
PSYCHOMOTOR EDUCATION, AN ASPECT OF GENERAL FORMATION OF THE PRE-SCHOOL CHILDREN
}

\author{
Ardian Shingjergji \\ ardianshingjergji@gmail.com \\ University of Elbasan "Aleksandër Xhuvani", Albania

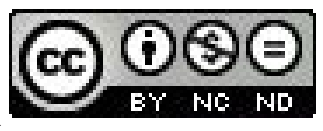

\begin{abstract}
Current developments of scientific thinking in the field of education, are increasingly demanding in various disciplines for young people as a matter of urgency. It is already known that child development is conditioned by ancestry, socio-cultural environment, including interaction with peers and adults. Albanian institutions (kindergarten) compared to contemporary experience in more developed countries have to deal with issues such as: (1) The development of a run or optimal acceleration enrichment motor for kindergarten children, seen as an important element of the formation of the human personality and its preparation to cope with various situations of life ; (2) The role of infrastructure in the natural development of the personality of children and the educational process as a whole; (3) Parental community involvement as a fundamental prerequisite of real development of the child; (4) The qualification level of the teaching staff in the elementary education system and the preparation of students teacher.

I hope to add my contribution through this paper, not only by identifying the problems above, but also in presenting alternatives of a development model of kindergarten children motors skills progress, compared to contemporary experience in more developed countries.
\end{abstract}

Key words: education psychomotor, motoric experience, kindergarten children, run motoric development, model motors skills progress.

\section{INTRODUCTION}

The present days' developments of scientific thought in the field of education are seen more and more as an immediate problem, different disciplines led to the intervention in a timely manner to young people, ranging from preschool age, when organized education starts.

There is no doubt that the all-round development of the child is achieved through the integration of the field of knowledge with social, emotional and physical ones, and this development is a product of biological maturity liaison environment in which he/she grows up. But here we must consider the fact that development does not occurs at the same period for all children and that they manifest different ways of the process of knowledge and learning.

All these aspects are related to education and development of children, underlying pre-school education curricula today, with models such as: "Reggio Emilia", 
"Montesori", "Frobeli", "Step by Step". Such curricula, which are embedded progressive ideas as education colossus: Jean Piaget, Lew Wygotsky, Jerome Bruner and Howard Gardner, reflect project work and take into account the fact that children are considered as social beings, competent and demonstrate direct physical and social experience as well as knowledge.

This paper aims to address some of the issues and problems which deal with:

Firstly, the Albanian reality of the education system in general and the psychomotor one in particular, including curriculum, programs, human and financial resources compared to the standards of developed countries.

Secondly, with the parental community involvement as a fundamental prerequisite of real child development and preschool teaching staff qualification level of preparation of students educators.

Thirdly with the approaching age of children with the motor run practice, the enriching experience and optimal acceleration motor as a very important element of the formation of the human personality and its preparation in facing the challenges of life or as an aspect of their approach various sports disciplines and early identification of talent.

Regarding the first issue, we are based on a close recognition of the problem that presents the current reality of preschool children in our preschool education, compared to the standards of the most developed countries. In the focus of our study it have been, observation, the curriculum of preschool research where the following are included:

- The designed education program of preschool education by specialists and approved by the Ministry of Education and Science (MASH).

- Other educational materials that build and guide the work in kindergartens.

In Albania as in many other countries of the world, the control of education is a responsibility and duty of the state and preschool education is the first link of our educational system. Actually this link is represented by the unified system of public and private kindergartens.

It should be accepted the fact that during the last decade preschool education as well as its other links are subject to a whole process of change and this is seen in the inclusion of curricula, programs with advanced elements in accordance with the new philosophies of education. Evidence of this progress are not reflected only in changes in the configuration of the learning environment, but as well in the concrete work that it is done with the children, where it is worth mentioning the inclusion of many elements of contemporary methodologies to educate children as well as the inclusion of content standards, which serve to enhance the quality of education.

In reviewing the preschool program on motor education, we face two important areas (lines) leading to these standards.

- Physical health

- Motor development where it is included the great motor and the fine motor.

However, pre-development rates in the past 15 years have been slow. The fact that this education link is not in compulsory education, has conditioned the lack of attention of all Governments, which is reflected in the continuous reduction of funds allocated to it. As well, preschool curriculum with all the changes, it is still far from being flexible by not responding enough to the reality in taking into account 
the specific conditions of different regions which differ from each other as economic opportunities, human resources as well school infrastructure and materials.

Furthermore, we list some of the indicators of pre-school education published by the Ministry of Education and Science in education strategy for the years 2009-2013, compared with the other European countries.

1. The index of participation of children in kindergartens in 2009 was at $50 \%$ and is projected to reach $70 \%$ in 2013 . This indicator compared to the high percentage of participation of children in most European countries, makes us reflect on the level where we are and the importance of participation or availability of appropriate preschool curriculum.

2. The number of children in the group and teacher-child relationship. In our kindergartens this report for 2008 has been 1-19.8, and with a tendency to decrease, but is still far from European countries indicators, which is 1-15.

3. Human and financial resources such as adequate physical facilities for preschool children, heating systems, educators teacher's salaries and the index of the training and the qualification of educator teachers, which is still at low levels (40\% in $2010,80 \%$ in 2013).

Regarding the second issue, that of parental involvement in the life and activity of children in kindergarten and preschool institutions teaching staff training was done and still is done continuous effort in order that these two indicators increase. The children are represented by the Board of Parents and receive information about kindergarten education program and are part of decision-making in financial management policies to meet the real needs of children

As well, about the other indicator, that of continued qualification training of the teaching staff and the assistance in the kindergarten as one of the basic conditions to increase the quality of education, efforts have been made in this direction.

Despite all the efforts and changes in preschool curriculum programs, we notice with regret that they remain covered only on paper and very little is done to enforce these two indicators in the concrete-educational learning activity.

Regarding the third issue, that of handling problems psychomotor education to preschool children, we can say that the synthesis of the views of different authors is to develop motor skills in accordance with the age and physic maturity. The growth and development are natural factors that affect on one hand, but on the other hand, at the same important and crucial to this development are the factors as:

- Environment

- Exposure (the possibility to take part in motor activities).

- $\quad$ The implemented instructions and guides (Gallahue, \& Ozmun, 1988).

\section{MOTOR SKILLS DEVELOPMENT AND PSYCHOMOTOR EDUCATION COMPONENTS}

Motor skills development cannot be a spontaneous and unled activity as children need care, instructions and appropriate programs to develop them in the direction of the desired way (Grineski, 1992; Bredkamp, \& Copple, 1997). 
The first years of the involvement of children in motor activity are very important, as they may be called, referring to a remarkable statement as "the golden years of the development of skills".

Preschool age is not a single phase, in terms of features in the proper execution of movements. The basic motor elements taken through psychomotor education starts about the age of 3-4. In the age groups following, these elements become more apparent by emphasizing even the tasks that this education has for every stage of the development of children in kindergarten.

The education program for children in the kindergarten predicts at least half an hour a day of psychomotor education. The diagram below presents the components of psychomotor education components during teaching sessions held in the kindergarten with the children.

Fig. 1. Kindergarten Physical Education graphic.

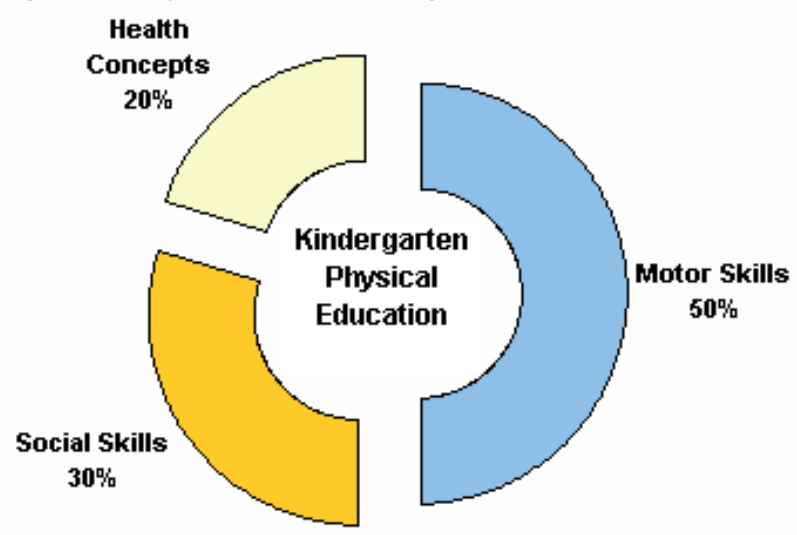

Source: Tammy Haag (Physical Education teacher).

Motor skills - 50\%

All the motor skills that are learned and developed in school, prepare "the building" to achieve the desired physical conditions, coordination and sports skills.

1. Motors skills are divided into four main categories involved in teaching sessions each week:

2. Manipulative skills, which include movements such as jumps, throws, catches, strikes, flips, etc. The use of balloons, balls, rings and rods during the activities make the latter quite enjoyable for children.

3. Loko-motor skills, which include exploratory movements such as jumping, running, dancing, etc.

4. Simple Games (at a modest level of organization), which significantly impact on the social development of children through the development of solving situations, decision making ability, group collaboration, these skills, which can be developed only being in a larger social group.

5. Fitness, where there are included exercises and activities to maintain a healthy body. 


\section{Social skills - $30 \%$}

These skills can be educated and developed during session lessons where are included those kinds of programs where children can learn how to express their feelings toward the others and how to know others' feelings. Videos and games with role plays in classroom are different situations, where children are in a closer relationship with one - another, so they can learn more.

\section{Concepts about health $-20 \%$}

In kindergarten children can take the gist knowledge about their body and how to look after it. Through an activity known "outer anatomy" they learn from what their body consist on and how their organs work. Concepts about exercise, food, certainty and cleanness are learned through video, activities and games.

When the three divided components, are linked together, the graphic turns into a complete circle of skills, which are linked and coincide with the growth and development of children.

The effective time spent during skills education in kindergarten is bigger because the motor skills and social skills are emphasized during game's time in the kindergarten environment.

Researches related to this point of view have shown that children who play (exercise) grow their functional capacity in their organism as the adults. Whereas, children who do not have the opportunities for exercising in the time when their organism is in growth, they can forever lose their functional ability.

\section{General characteristic for the motor development}

If the precedent phase, that of early childhood, is characterized over all by learning and improvement of different forms of movements, the main tendencies of motor development from 3 to 6 years old, are the perfection of movement forms and the education of the first movements (motor combination).

This fast development and vigorous childish forms of movement is expressed into three main directions:

1. As a faster quantitative growth of results,

2. As a qualitative improvement,

3. As a considerable growth for the opportunity of using simple movement forms in different situations or tasks.

How much true these affirmations are the following table helps us understand it better, as it shows a comparative format to the average of search results from 3 to 6 years old (Meinel, \& Schnabel, 1984). We ought to bear in mind that in this age, the differences between two genders are negligible.

Table 1. Comparative format to the average of search results from 3 to 6 years old.

\begin{tabular}{|l|l|l|l|}
\hline \multicolumn{1}{|c|}{ Indicators } & 3-4 years old & \multicolumn{1}{|c|}{$5-6$ years old } & Growth (\%) \\
\hline Running $40 \mathrm{~m}$ & $13.6 \mathrm{sec}$ & $9.9 \mathrm{sec}$ & $138 \%$ \\
\hline Height jumping from the same place & $47.8 \mathrm{~cm}$ & $116.7 \mathrm{~cm}$ & $243 \%$ \\
\hline Kicking the ball over head. & $3.79 \mathrm{~m}$ & 12.90 (Popov. 1971) & $340 \%$ \\
\hline
\end{tabular}

Source: Meinel, \& Schnabel, 1984. 
Among the main factors of the fast progress for the pre-school children, between others we mention:

- The considerable growth of associating and the social changeable position of children,

- The gradual approach in the school age (Otto, 1971).

As a result of fast motored progress, we have as a consequence as well a faster development of their intellectual capacity. An evident test among others, it is even the linguistic progress, which determines their motored attitude in the process of learning. So for example: we can mention the fact of the linguistic children's ability from 5 to 6 years old and children's vocabulary, which reaches 3 thousand words in comparison with three years old children (Novogrodoski, 1969).

If the motor task which needs to be realized it's clearly formulated and in adaption with their understanding skills, the children of this age understand words and react according to instructions with the right movements.

The fast rhythm of motor development of pre-school children determines even their motor behavior, which is visible from an impulse which is considered to be active.

The children of this age need something to deal with, to move continually and in different ways. In comparison with the children of age 3 to 4 , to the children of age 5 to 6, it is gradually reduced the tendency of changing the activities of games and the quick movement of their interests. They are dedicated to an activity of game with passion and more seriously.

Always referring to the development of more skills, the pre-school age can be determined as their phase of perfection and richness. Comparing the motor skills of 5-6 years old children to those of 3-4 years old, we can see considerable changes with the tendency of growing in the abilities of jumping, speed, equilibrium and kicking the ball, climbing, creeping as well as adaption and transformation of their movements.

These changes can be reflected for example: in the moving structure of walking, where it is needed to be emphasized the reducing number of paces and the growth approximately $10 \mathrm{~cm}$ of their length.

According to the development of running skills, the \% of well coordinated movements of their arms and legs, and according to their age varies from $30 \%$ to $90 \%$.

Table 2. Comparative format of the percentage of well coordinated movements.

\begin{tabular}{|l|l|l|}
\hline Age: 4 years old & Well coordinated movements & $30 \%$ (of children ) \\
\hline Age: 5 years old & Well coordinated movements & $70-75 \%$ (of children) \\
\hline Age: 6 years old & Well coordinated movements & $90 \%$ (of children) \\
\hline
\end{tabular}

Source: Levi-Gorinewskaia, 1955.

The increase of length of paces is accompanied by the increase of their frequency (speed of running). Children of the age 3-4 years old can do moveable tasks in which should pass difficulties of $20-30 \mathrm{~cm}$ length, on the other hand children of the age 5-6 years old are able to jump in 30-40 cm height but also this level of development needs that children practice it regularly, even between those who frequent regu- 
larly the learning sessions in kindergarten, only $1 / 3$ are able to adopt in those levels (Lewin, 1967).

The problems faced in education and the development of the motor skills in our pre-school institutions

Education and the development of motor skills in our pre-school educational system, despite the interference and improvements done, yet it isn't in the desired level or in the level of experience in this direction. Among the main reasons we should mention:

- Not being enough included in the pre-school educational program from some indicators that are linked with education and the development of basic motor skills, such as, the indicators' results of age groups of: running, jumping, catching, and kicking the ball, equilibrium.

- The lack of estimating tests in the basic motor skills in concord with the group-age characteristics.

- The lack of infrastructure and necessary didactic tools prevent the realization of developed motor skills program in the desired direction.

- The lack of training and the qualification of teachers like in the aspect of educating pre-school children in general as well as in the motor one in particular.

- The lack of training or not enough involvement of parents like a helpful and very important factor in the education and development of children's motor skills.

\section{Surveys and results}

The majority of pre-school children that frequent kindergarten are a few or aren't at all included in the motor skills. The landscape is shown like that; the time children stay in kindergarten is conceptualized like a vegetation period and with a low motor activity.

We came to this conclusion as a consequence of surveys done for a period of about 2-3 years in cooperation of professor-student, during teaching practicum done from Education Faculty it is supported by the poll results through questionnaires from two category groups of interest:

1. Kindergarten directors and educators.

2. The community combined by parents.

There are included in the polls ten kindergarten:

- In Elbasan, the pilot kindergarten," A. Arapi" and public kindergarten "7 March".

- In Librazhd, the public kindergarten "Nr 1" and "Nr 2".

- In Gramsh, the public kindergarten "Nr1" and "Nr 2".

- In Lushnje, the public kindergarten "Nr1" and "Nr 2".

- In Berat, the public kindergarten "Nr.1" and "1 Qershori".

Below we are presenting some of the questions that are included in the polls and the results obtained for questionnaire nr1 (Kindergarten directors and educators). 1 - Do you have enough knowledge about psychomotor education and its standards?

$$
\begin{array}{cl}
\text { a- Yes } & \text { b- No } \\
42 \% & 58 \%
\end{array}
$$


2- Does the program predict clear and specific objections regarding education and its progress in motor skills, according to age groups?

$\begin{array}{cc}\text { a- Yes } & \text { b- No } \\ 38 \% & 52 \%\end{array}$

3- Have you ever done trainings and other kinds of qualifications, regarding psychomotor education by specialists of this field?

$$
\begin{array}{cc}
\text { a- Yes } & \text { b- No } \\
33 \% & 67 \%
\end{array}
$$

4- From all the tools that realize children's pre-school psychomotor education, whose elements of developed psychomotor abilities are those which are more typical?

$$
\begin{array}{cc}
\text { a- fine motored } & \text { b- Big motored } \\
44 \% & 56 \%
\end{array}
$$

5- Is it understandable, while working with children, the need of an adaptable model of the psychomotor education, with contemporary educational models?
a. Yes
b. No
$75 \%$
$25 \%$

Fig. 2.1. Knowledge about psychomotor education and its standards.

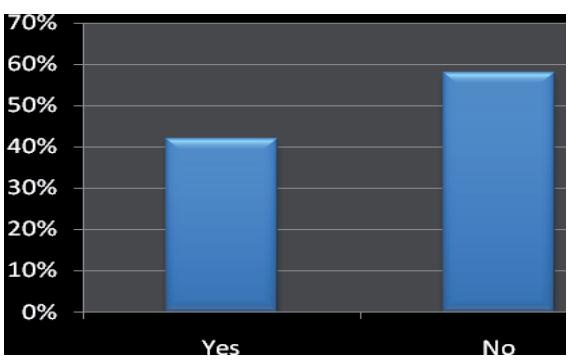

Source: Own chart.

Fig. 2.3. Trainings regarding psychomotor education.

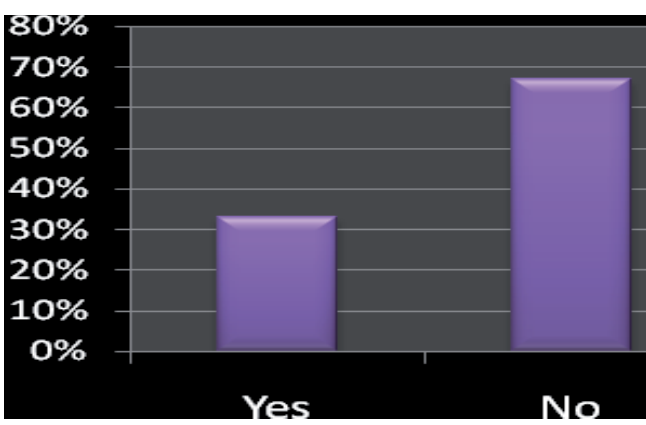

Source: Own chart.
Fig. 2.2. knowledge about the programme and specific objections.

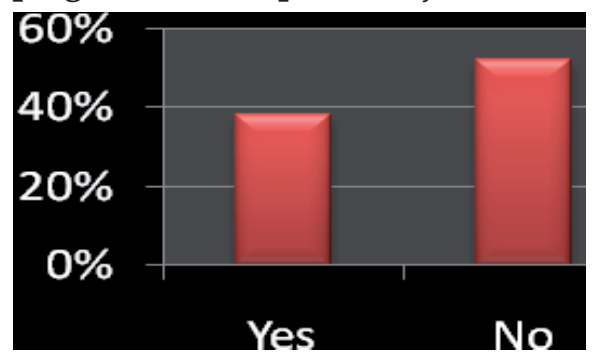

Source: Own chart.

Fig. 2.4. Typical elements of developed psychomotor abilities.

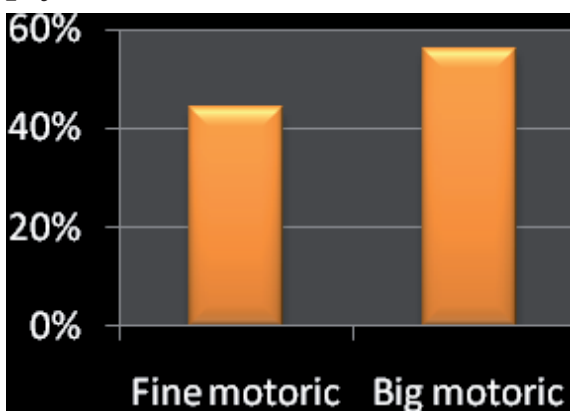

Source: Own chart. 
Fig.2. 5. The necessity for contemporary educational models.

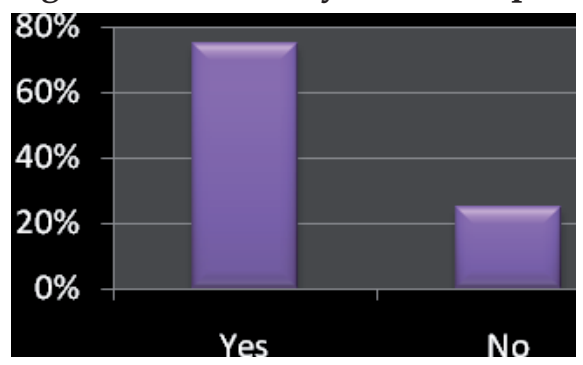

Source: Own chart.

Questionnaire nr. 2 for parents.

1 - Do you know about the place that occupies in the program the psychomotor education as one of the key aspects of the overall development of the personality of your child?
a. yes $30 \%$
b. no $70 \%$

2 - Do the educators, leaders of the kindergarten inform you about the normal progress or motors deficiencies, physical health, and body deformations of your child?
a. Yes
b. No
$67 \%$
$33 \%$

3 - Which of the following elements are more interested in?
a. Physical Health
b. Motor conduct
c. Overweight $48 \%$
$20 \%$ $32 \%$

4 - Do you follow at home conditions the complimentary tasks related to the fulfillment of deficiencies of motor development, that your child faces up?
a. Yes
$34 \%$
b. No
$66 \%$

5 - Which of the following factors hinder you or restrict you in realizing your child additional duties in the home conditions?
a. Time b. Commitment
c. Information
d. Training
e.economic conditions
f. Building's surface
$10 \%$
$18 \%$
$12 \%$
$27 \%$
$20 \%$
$13 \%$

Fig.3.1. Knowledge about the psychomotor education.

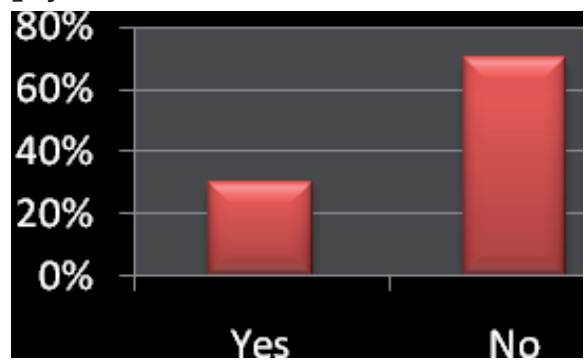

Source: Own chart.
Fig.3.2. The information that educators give about the normal progress.

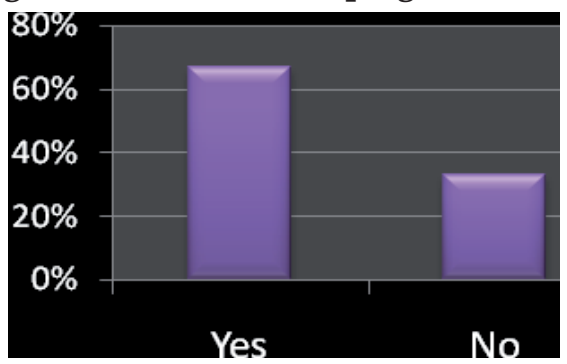

Source: Own chart. 
Fig. 3.3. Interest in the shown elements. Fig. 3.4. Following the complimentary tasks.

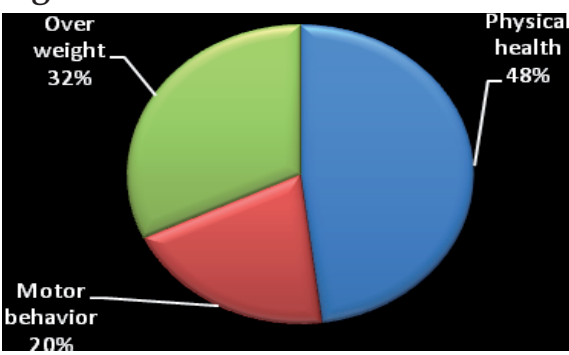

Source: Own chart.

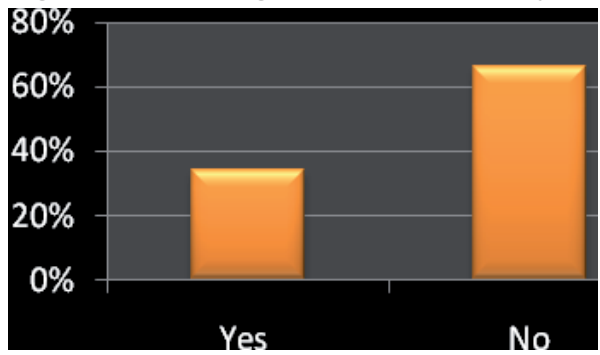

Source: Own chart.

Fig.3.5. Restricting factors that hinder partents into realizing the child additional duties.

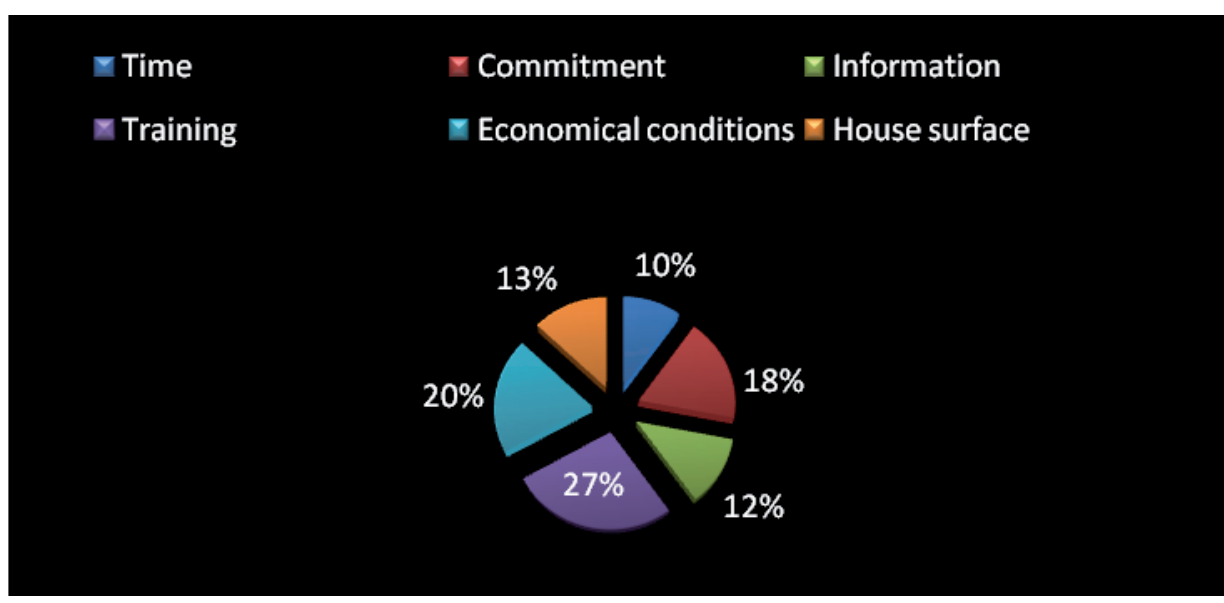

Source: Own chart.

In reviewing the results of the survey came to the following conclusions:

- The data obtained (in \%) from the questionnaire responses indicate a lower level of information and knowledge about psychomotor education, by teacher leaders and educators, and by parents.

- Qualification and training of both interest groups involved in the survey are presented at unsatisfactory levels by reinforcing the need and necessity of the contribution of specialists in imparting knowledge or teaching instructions in this area.

- Even in the Faculty of Education which prepares teacher -educators, the course of psychomotor education is a relatively new course. As such, it has its shortcomings and there is room for improvement and intervention, especially in the provision of knowledge or subject-integrated methodologies.

- The contributing part of questionnaire data served to reinforce once more our findings that the quality of psychomotor education in our school institutions is simplified, spontaneous and not based on the instructions necessary to comply with age, without goals and clear objectives that resemble more to casual education. 
- And at the end of the survey, the results demonstrate the need for a simple model of functional education and motor skills development, especially in terms of assessing their achievement.

\section{Field - Development of basic motor skills (Great Motors)}

Below we are reflecting a detailed format (model) of the field of development of basic motor skills, in accordance to their development and age.

Table 3. Standard 1: Development of basic motor controlling skills.

\begin{tabular}{|l|l|l|}
\hline \multicolumn{1}{|c|}{ Age 3-4 years } & \multicolumn{1}{|c|}{ Age 4-5years } & \multicolumn{1}{c|}{ Age 5-6 years } \\
\hline $\begin{array}{l}\text { 1.Children go up and } \\
\text { down the stairs without } \\
\text { being held to their } \\
\text { carriers }\end{array}$ & $\begin{array}{l}\text { 1. Children catch and receive } \\
\text { a large ball with both hands. } \\
\text { 2. Walking and jogging } \\
\text { (Organized games that simulate } \\
\text { capturing and reception of the ball) }\end{array}$ & $\begin{array}{l}\text { 1. Children pass around } \\
\text { various obstacles } \\
\text { ignoring or passing } \\
\text { 2. Walking and jogging } \\
\text { them. }\end{array}$ \\
$\begin{array}{l}\text { 20-30m distance. } \\
\text { 2. Walking and jogging } \\
\text { (Games and relay motor speed } \\
\text { capability stimulated). }\end{array}$ & $\begin{array}{l}\text { (Organized games and } \\
\text { relay motor speed skills } \\
\text { education). }\end{array}$ \\
\hline
\end{tabular}

Source: Standardet e Arritjes nw Arsimin Parashkollor, (2004); Standardet e Përmbajtjes në Arsimin Parashkollor, (2002); Standardet e Zhvillimit dhe të Mësuarit në Fëmijërinë e hershme 0-6 vjec, 2011.

\section{Table 4. Standard 2: Development of equilibrium skills.}

\begin{tabular}{|c|c|c|}
\hline Age 3-4 year & Age $4-5$ years & Age 5-6 years \\
\hline $\begin{array}{l}\text { 1. Children bring the } \\
\text { ball to themselves, in } \\
\text { a sitting position and } \\
\text { not crashing. } \\
\text { 2. Children stand on } \\
\text { one foot for } 5 \text { sek. }\end{array}$ & $\begin{array}{l}\text { 1. Children stand on one foot for } 10 \text { sek. } \\
\text { (Stimulates body movements } \\
\text { accompanied by music, combined with } \\
\text { small vacation stays on one foot). } \\
\text { 2. Children walk in a straight line, thin } \\
(2-3 \mathrm{~cm}) \text {, while maintaining balance. }\end{array}$ & $\begin{array}{l}\text { 1. Children easily } \\
\text { bridge tall objects of } \\
30-40 \mathrm{~cm} \text { height } \\
\text { 2. Children jump on } \\
\text { one foot without } \\
\text { losing balance. }\end{array}$ \\
\hline
\end{tabular}

Source: Standardet e Arritjes nw Arsimin Parashkollor, (2004); Standardet e Përmbajtjes në Arsimin Parashkollor, (2002); Standardet e Zhvillimit dhe të Mësuarit në Fëmijërinë e hershme 0-6 vjec, 2011.

\section{Table 5. Standard 3: Development of motor coordinating skills.}

\begin{tabular}{|c|c|c|}
\hline Age 3-4 years & Age 4-5 years & Age 5-6 years \\
\hline $\begin{array}{l}\text { 1. Children throw the ball in the } \\
\text { right direction. } \\
\text { (Children try to throw the ball } \\
\text { accurately in some baskets in } \\
\text { a circle or square, as well as } \\
\text { organized games with the team). } \\
\text { 2. Ups and downs over the } \\
\text { knees keeping the body straight. } \\
\text { (Stimulated motor activity } \\
\text { associated with the music.) }\end{array}$ & $\begin{array}{l}\text { 1. Children run } \\
\text { to the rhythm } \\
\text { of music (faster, } \\
\text { slower,). } \\
\text { 2. Children can } \\
\text { ride the bike in the } \\
\text { front and rear } \\
\text { (Imitating games } \\
\text { organized bicycle } \\
\text { cycling.) }\end{array}$ & $\begin{array}{l}\text { 1. Children jump easily over a } \\
\text { drawn surface. } \\
\text { (Jumping on the circles drawn } \\
\text { on the floor and set the distance } \\
\text { of different ways. Jumping rope } \\
\text { individually or collective.) } \\
\text { 2. Children take positions to } \\
\text { imitate different movements like } \\
\text { walking, running or dancing of } \\
\text { people or animals, etc. }\end{array}$ \\
\hline
\end{tabular}

Source: Standardet e Arritjes nw Arsimin Parashkollor, (2004); Standardet e Përmbajtjes në Arsimin Parashkollor, (2002); Standardet e Zhvillimit dhe të Mësuarit në Fëmijërinë e hershme 0-6 vjec, 2011. 


\section{CONCLUSIONS}

1. Through the issues involved in this work we have tried to bring the synthesis of contemporary views about psychomotor education as a fundamental aspect of the education of preschool children.

2. The development and enrichment directed to the movement experience of pre-school children is a very important factor that directly affects the strengthening of the health and the formation of their democratic citizen personality.

3. The preschool children's motor skills are trained and developed in accordance to the age and maturity, where factors such as: the environment, motor activity and adequate instructions, play a determining role in this development.

4. Stressing once again the strong need for children to move, we must pay attention to their motor activity leadership with appropriate programs and in the desired way.

5. Education and development of motor skills requires the involvement of infrastructure and necessary didactic tools for teaching, continuous education of teachers' and parents' training as a very important factor in this regard.

\section{REFERENCES}

Bredkamp, S., \& Copple, C. (Eds.). (1997). Developmentally appropriate practice in early childhood programs. Washington, DC: National Association for the Education of Young Children.

Gallahue, D. L., \& Ozmun, J. C. (1998). Understanding motor development: Infants, children, adolescents, adults ( $4^{\text {th }}$ ed.). Boston, MA: McGraw-Hill.

Grineski, S. (1992). What is a truly developmentally appropriate physical education? Program for children, "Journal of Physical Education, Recreation and Dance", 63 (6), 33-35.

Kagan, L. Sh \& Britto, P. R (2005). Going global with Early Learning and development Standards. NY: The National Center for Children and Families Teachers College, Columbia University.

Mato, E. (2002). Treguesit arsimit parashkollor në ndihmë të vlerësimit të sistemit dhe institucioneve parashkollore [Pre-school education indicators at aid of assessment of the pre-school system and institutions]. Tiranë: Nr.1, botim ISP.

Meinel, K. (1984). Teoria del movimento. Societa Stampa Sportiva. Roma.

Spodek, B., \& Saracho, O. (1994). Right from the start: Teaching children age's three to eight. Boston: Allyn and Bacon.

Standardet e Përmbajtjes në Arsimin Parashkollor [Content and Standards in Preschool Education]. (2002). Tiranë: botim ISP, Zyra e Statistikave, (Statistics' Office) MASH.

Standardet e Arritjes në Arsimin Parashkollor [Achievement Standards in Education Preschool] (2004). Tiranë: botim ISP, Zyra e Statistikave, (Statistics' Office) MASH.

Standardet e Zhvillimit dhe të Mësuarit në Fëmijërinë e hershme 0-6 vjec [Standards Development and Learning in Early Childhood 0-6 years] (2011). Tetor: M.A.SH.T.

Van de Gaag, J. (n.d.). From Early Child Development to Human Development. Retrived April 29, 2013, from http://www.ecdgroup.com/pdfs/van_der_gaag_paper_childdev-20_05_2003-18_13_22.pdf. 